Published in final edited form as:

Curr Opin Oncol. 2011 September ; 23(5): 475-481. doi:10.1097/CCO.0b013e328349c233.

\title{
HIV-associated Multicentric Castleman Disease
}

Deepa Reddy, MD and

University of California Los Angeles, UCLA Hematology Oncology, Box 957059, Suite 2333

PVUB, Los Angeles, CA 90095, 310-206-8477, dreddy@mednet.ucla.edu

\section{Ronald Mitsuyasu}

University if California Los Angeles

\begin{abstract}
Purpose of review-HIV-associated multicentric Castleman disease (HIV MCD) is a rare lymphoproliferative disorder, the incidence of which appears to be increasing in the highly active antiretroviral therapy (HAART) era. Current knowledge of the disease is limited and this review will discuss what is known about the pathophysiology, diagnosis, management, and prognosis of HIV MCD.
\end{abstract}

Recent findings-HIV MCD has been shown to be associated with infection with human herpervirus-8 (HHV8). Vascular endothelial growth factor and the cytokine interleukin-6 (IL-6) are also thought to play a role in the pathogenesis of MCD. Currently, rituximab is often used alone or in combination with chemotherapy for treatment of MCD. Novel monoclonal antibodies targeting IL- 6 and the IL- 6 receptor are also being studied for the management of this disease.

Summary-Because HIV MCD is an uncommon diagnosis, comprehensive clinical studies have not been done, and understanding of the disease is incomplete. Further studies are needed to make definitive conclusions regarding optimal treatment of HIV MCD.

\section{Keywords}

Multicentric; Castleman; HIV

\section{Introduction}

Castleman disease (CD), also known as angiofollicular or giant lymph node hyperplasia is an uncommon lymphoproliferative disorder, with heterogenous manifestations ranging from asymptomatic disease to recurrent episodes of widespread lymphadenopathy with systemic symptoms. The exact incidence of $\mathrm{CD}$ is unknown, but the estimated number of cases in the US ranges from 30,000 to 100,000 . (1) The disease has become increasingly relevant in recent years given its association with human immunodeficiency virus (HIV) and with human herpesvirus (HHV)-8.

CD was first described at Massachusetts General Hospial in 1954 by Dr. Benjamin Castleman who described a patient with solitary hyperplastic mediastinal lymph nodes

Conflict of Interest: None 
characterized by regressively transformed germinal centers. (2) He subsequently reported on 13 patients with benign mediastinal lymphadenopathy, most with follicular hyperplasia and capillary hyalinization. (3) This subgroup is now known as the hyaline vascular variant of CD. During the 1960s, a new variant of CD was described that lacked hyalinization, had concentric sheets of plasma cells surrounding the germinal centers and in the interfollicular space, and was often associated with systemic manifestations. (4) This became known as the plasma cell variant of $\mathrm{CD}$. In addition, given that some patients present with localized lymphadenopathy, whereas others have disseminated disease, $\mathrm{CD}$ has also been divided into unicentric $\mathrm{CD}$ and multicentric $\mathrm{CD}(\mathrm{MCD})$. More recently, a third subtype of $\mathrm{CD}$, known as plasmablastic MCD, has been identified. This subtype is multifocal, behaves more aggressively, and was first described in association with POEMS (polyneuropathy, organomegaly, endocrinopathy, monoclonal gammopathy, and skin changes). In this variety, involved nodes contain large abnormal plasma cells with prominent nucleoli and copious cytoplasm in the mantle zones. (5,6) (Figure 1) Plasmablastic MCD is found with increased frequency in HIV-infected individuals, and the incidence of HIV-associated MCD appears to be increasing in the HAART era. (7)

Because multicentric $\mathrm{CD}$ is an uncommon diagnosis, comprehensive clinical studies have not been done, and understanding of the disease is incomplete. This article will discuss what is currently known about the pathophysiology, diagnosis, management, and prognosis of MCD in HIV-infected individuals.

\section{Pathophysiology}

Human herpesvirus-8 (HHV8) and cytokine dysregulation including increased levels of VEGF and interleukin (IL)- 6 have been recognized to have a role in the pathogenesis of MCD.

\section{HHV8}

During the emergence of the AIDS epidemic, clinicians recognized that Kaposi's sarcoma (KS) and MCD often coexisted. (8, 9, 10) In 1990s, Kaposi's sarcoma herpesvirus (KSHV), also known as HHV8 was isolated and linked to a number of diseases including MCD. (1114) In the first study linking the etiology and pathophysiology of MCD with HHV8,17 HIVnegative and $14 \mathrm{HIV}$-positive individuals with MCD, and $34 \mathrm{HIV}$-uninfected control individuals with reactive lymph nodes and no histopathologic features of MCD, were assessed for presence of HHV8 by PCR in excised lymph nodes. Of the 17 HIV-uninfected participants, $41 \%$ showed evidence of HHV8 infection. All 14 of the HIV-infected individuals, but only one of the control patients had HHV8 detectable in lymph nodes. (15) Suda et al examined 82 paraffin-embedded lymph nodes from patients with MCD for the presence of HHV8, which was detected in only three (4\%) samples, all from individuals who were HIV-infected. (16) Given this data, it was believed that the HHV8 was always present in HIV MCD; however, the first case report of MCD in an HIV-positive individual with undetectable HHV8 based on PCR and immunohistochemistry (IHC) was reported in 2003. (17) 
Although, this recent report may suggest other possible etiologies for development of MCD in HIV-infected individuals, other lines of evidence also support the role of HHV8 in the pathogenesis of MCD. First, in HIV-infected individuals, the quantity of HHV8 in peripheral blood mononuclear cells (PBMCs) or plasma has been noted to correspond with symptoms during MCD flares. (18-24) Additionally, there appears to be a high degree of HHV8 replication, with mostly lytic genes active in infected cells in patients with MCD, and administration of antiviral therapies has been associated with regression of symptoms in some HIV-infected patients with MCD. (24-26)

Given this data, it is evident that HHV8 plays a role in the pathogenesis of HIV MCD; however, the causality of HHV-8 in the development of HIV-associated MCD has not yet been established and should be the subject of future investigations.

\section{VEGF}

Vascular endothelial growth factor (VEGF) is a cellular signal protein which stimulates angiogenesis. Foss et al examined lymph nodes from eight patients with unspecified variants of $\mathrm{CD}$ and compared them to tonsillar tissue in patients with infectious mononucleosis. VEGF was detected by in situ hybridization (ISH) in five of eight germinal centers in those with $\mathrm{CD}$, and in none of the controls. (27) Nishi et al examined one patient with the unicentric plasma cell variant of $\mathrm{CD}$ and one patient with $\mathrm{MCD}$, both who had elevated levels of serum VEGF which then fell to normal after nodal resection and chemotherapy respectively. VEGF levels were 100-times higher from the supernatants of the affected nodes compared to a control node, and nearly all plasma cells from the interfollicular region of both nodes stained positive for VEGF by ISH. (28) These studies suggest that VEGF may play a role in the pathogenesis of $\mathrm{CD}$, but further studies are needed to elucidate its role in pathways leading to development of this disease.

\section{Interleukin-6}

IL-6, a cytokine involved in the acute inflammatory phase reaction, has been recognized to play a role in the pathogenesis of CD. (29) Yoshizaki et al performed a study which found IL-6 in the germinal centers of lymph nodes from patients with unicentric plasma cell variant $\mathrm{CD}$ and $\mathrm{MCD}$. Also, serum IL-6 levels were noted to be elevated in the patient with unicentric $\mathrm{CD}$, and declined along with resolution of symptoms and lab abnormalities after resection of the node. (30)

A study done in mice showed that expression of a murine IL-6 gene caused an MCD-like syndrome. (31) Additionally, patients have been found to have elevated serum IL-6 levels during symptomatic episodes of MCD, which become normal again after treatment. (20, 32, 33)

One possible source of IL-6 production in MCD may be from cells infected with HHV8. HHV8 encodes a viral homologue of IL-6 (vIL-6) which can stimulate the known human IL-6 (hIL-6) induced signaling pathways. (34-38) Studies in mice and human cell lines have shown that vIL-6 supports cell growth and survival in vitro in a similar manner to hIL-6. In mice, recombinant vIL-6 induced a marked plasmacytosis similar to that found in MCD, as 
well as accelerating hematopoesis and inducing VEGF. (39) vIL-6 has also been shown to induce production of hIL-6 in cells harvested from a lymph node of a patient with MCD, thus providing a link between HHV-8 infection and higher levels of hIL-6.

Observational studies have also supported the role of HHV8 and vIL-6 in CD. vIL-6 has been found to be expressed in the lymph nodes of both HIV-negative and HIV-positive individuals with CD. (40-42) Elevated levels of vIL-6 which were noted in the blood of a patient symptomatic with HHV8 associated MCD, decreased with prednisone and foscarnet treatment. (43)

\section{Clinical Presentation}

Individuals with MCD present with symptoms consistent with an inflammatory process. Affected patients are typically older than those with unicentric disease, with median age at presentation in the 50s-60s. (44) Studies have not found that prevalence varies by gender. (45-47) A retrospective study of 20 HIV-infected individuals with MCD showed that the main presenting symptoms were fever, peripheral lymphadenopathy, hepatosplenomegaly, weight loss, respiratory symptoms, and edema. (48) Additionally, all patients had anemia, elevated C-reactive protein, polyclonal hypergammaglobulinemia, hypoalbuminemia, and seven patients were pancytopenic.

The increased vascular permeability caused by VEGF can lead to pleural effusions and ascites. $(49,50)$ The disease can either be persistent with gradual worsening of symptoms or present as episodic exacerbations. (51)

MCD patients often have some manifestations of POEMS syndrome, which is seen in up to $15 \%$ of MCD cases (52). However, peripheral neuropathy and monoclonal paraprotein with or without other features of POEMS are only rarely seen in patients with HIV. (53) IL-6 may cause immune dysregulation, leading to autoimmune phenomena. (54) Autoimmune hemolytic anemia and thrombocytopenia, pure red cell aplasia, acquired factor VIII deficiency, lupus, and myasthenia gravis have all been described.

\section{Diagnosis}

The differential diagnosis of HIV- associated MCD should include lymphoma, autoimmune disorders, and viral or bacterial infections. Examination of an excised lymph node is necessary to establish the diagnosis. The histologic characteristics of plasmablastic MCD include the presence of plasmablasts within the mantle zone of B-cell follicles. These plasmablasts are characterized by a moderate amount of cytoplasm and a large vesicular nucleus with 1-2 prominent nucleoli. IHC often reveals nuclear staining of B cells for HHV8-associated latent nuclear antigen-1. $(55,56)$ The plasmablasts express high levels of cytoplasmic immunoglobulin, that is always IgM lambda restricted. $(55,57)$ Despite the expression of monotypic IgM lambda, the plasmablasts have polyclonal immunoglobulin gene rearrangements and the HHV8 episomes are also polyclonal. $(57,58)$

The diagnosis of active HIV MCD also requires clinical features of active disease. There are no evidence based criteria for establishing a diagnosis of active MCD, but the French 
Agence Nationale de Recherche sur le SIDA 117 CastlemaB trial group have described criteria to define an attack of HIV MCD. (59) Patients require a fever, a C-reactive protein greater than $20 \mathrm{mg} / \mathrm{L}$ in the absence of any other cause, and 3 of 12 additional clinical findings (see Table 1).

In addition to excisional lymph node biopsy, work up in patients with HIV MCD should include HHV8 serology with quantitative HHV8 PCR, CBC, renal and liver function, and assessment for plasma cell dyscrasias including immunoglogulins, serum and urine protein electrophoresis and immunofixation, light chains, bone marrow biopsy and 24-hour urine for protein quantification. Patients should also be assessed for organ function with echocardiogram and PFTs. Imaging to assess extent of disease involvement can be done with either CT of the neck, chest, abdomen, and pelvis, or with whole body PET/CT. (49)

\section{Treatment}

The gold standard therapy for HIV MCD is yet to be established. Options for therapy include chemotherapy, monoclonal antibodies, immune modulators, and antiviral therapy.

\section{Chemotherapy}

The most commonly reported chemotherapy regimens for MCD in the literature are those modeled after the treatment of non-Hodgkin's lymphoma (NHL). Two series reported remissions with chemotherapy lasting anywhere from one to ten years in four out of six patients treated with cyclophosphamide, vincristine, doxorubicin, and dexamethasone (CVAD) and in two out of four patients treated with cyclophosphamide, vincristine, doxorubicin, and prednisone (CHOP). (45, 47) In a large study of 20 patients with HIVassociated MCD, nine patients treated with single agent vinblastine achieved a partial response, but only four patients remained stable with maintenance therapy, and five patients relapsed and required combination chemotherapy with adriamycin, bleomycin, and vincristine $(A B V)$ or partial splenectomy. Four patients received $A B V$ up-front with three having a partial response. Three patients received intermittent cyclophosphamide with partial response. (48) Oral etoposide has also been evaluated in individuals with MCD, with patients achieving a partial response. (60) The combination of chlorambucil and prednisone has been used in studies, with four of nine patients achieving a complete response. (45, 47, $51,61)$ More recently, chemotherapy combined with rituximab immunotherapy has shown efficacy. $(53,62,63,64)$

Given the small number of patients reported in these studies, there is little evidence on which to base treatment decisions and insufficient data to prefer one regimen of chemotherapy over another. Often the choice of chemotherapy is made based on how aggressive the disease appears.

\section{Monoclonal Antibodies}

Tocilizumab is a humanized anti-hIL-6 receptor monoclonal antibody. In Japan, tocilizumab was administered to $28 \mathrm{HIV}$-negative patients with MCD who were noted to have improved symptomatology, lymphadenopathy, and inflammatory markers. (65) This agent has been approved for treatment of CD in Japan, but is only approved in the US for treatment of 
rheumatoid arthritis. Siltuximab is a novel anti-IL-6 monoclonal antibody which was used for treatment of $\mathrm{MCD}$ and unresectable unicentric $\mathrm{CD}$ in a phase I study. Interim results reported that 18 of 23 patients achieved clinical benefit, and 12 patients demonstrated objective tumor response. All 11 patients treated with the highest dose of $12 \mathrm{mg} / \mathrm{kg}$ achieved clinical benefit and eight achieved objective response. These data suggest that siltuximab may be effective for treatment of CD. (66) Studies are needed to assess the efficacy of tociluzumab and siltuximab for treatment of HIV MCD.

Rituximab is a monoclonal antibody to CD20 that leads to cell death in cells expressing this surface marker. Although HHV8-infected plasmablasts frequently do not express high levels of CD20, several case series and open label studies have evaluated the use of rituximab in HIV-associated MCD. One study evaluated four weekly doses of rituximab at the standard dose of $375 \mathrm{mg} / \mathrm{m} 2$ in 5 patients with HIV MCD. Although two patients died very quickly after initiating therapy, three of the five achieved a complete remission. (67) Another study of 21 patients with newly diagnosed HIV MCD treated with four standard doses of rituximab reported a radiologic response rate of $67 \%$, overall survival of $95 \%$ at two years, and disease-free survival of $79 \%$ at two years. (68) A third study of 24 patients with chemotherapy dependent HIV MCD, reported that 4 weekly standard doses of rituximab induced a remission of at least 1-year duration in $71 \%$ and achieved a one-year overall survival of $92 \%$. (59) Although these studies suggest efficacy of rituximab for HIV MCD, two case series have described patients with aggressive HIV MCD and organ failure who failed to respond to rituximab monotherapy. $(69,70)$

Rituximab has also been studied for retreatment of patients with HIV MCD who had received previous treatment with rituximab. Three patients were rechallenged with rituximab, and all achieved a remission. (71)

A retrospective study analyzed 107 patients with HIV MCD who had received chemotherapy as first-line therapy. Thirty-five of these patients received rituximab at some point after diagnosis of MCD. The study found that 14 of 82 (19\%) patients who did not receive rituximab progressed to non-Hodgkin lymphoma (NHL), whereas only 1 of 35 (3\%) in the rituximab group progressed to NHL. The 3-year overall survival was $93 \%$ in the treated group versus $74 \%$ in the untreated group $(\mathrm{p}=0.01)$. (72) Another retrospective study found that clinical outcome for patients with HIV MCD were improved during recent years suggesting improved efficacy of rituximab-based treatment strategies. (73)

\section{Immune modulators}

Corticosteroids have been used to control the inflammation associated with $\mathrm{MCD}$, but have not been studied in clinical trials. In one study, six patients with MCD were treated with glucocorticoids, four of whom did not achieve a lasting response. (51) In another study, three of five patients treated with prednisone achieved a partial response. (74) However, in other case series, the few patients receiving prednisone alone only saw transient improvements while on the drug. $(45,46)$ A large number of individuals were noted to die of sepsis during therapy, and long term corticosteroid therapy can be associated with a high risk of infection. $(46,51)$ 
Interferon (IFN) alpha has both immunoregulatory and antiviral properties and was reported to achieve lasting remissions after administration of chronic therapy in two patients with HIV MCD. $(75,76)$ Thalidomide has immunomodulatory properties and may decrease production of IL-6, and has been described in the treatment of MCD in two HIV-negative individuals. $(77,78)$

\section{Antiviral Therapy}

Several antiherpes drugs including cidofovir, foscarnet, and ganciclovir have been reported to show activity again HHV8 in vitro. (79) However, these agents have had only limited success in treatment of HIV MCD. In studies with cidofovir, zero of seven patients responded. (24, 80-81) Two of four patients achieved remission with foscarnet. $(19,76,81$, 82) Ganciclovir and valgangiclovir induced remission in one patient and reduced frequency of relapse in two additional patients. (83)

It is uncertain whether HAART usage contributes to control of HIV MCD. Epidemiologic data has shown that the incidence of HIV MCD is increasing in the HAART era. (7) A review of the literature included 48 patients diagnosed with HIV MCD in the HAART era, of who $44 \%$ were on HAART at the time of MCD diagnosis, and of those $20(83 \%)$ had HIV viral loads less than 400 copies/mm3. (84) Case reports have also described acute deterioration of MCD symptoms upon starting HAART. $(19,85,86)$

However, other data has suggested that HAART is beneficial to patients being treated for HIV CD. A case series of seven patients with HIV CD on HAART showed a mean duration of survival of 36 months compared to a mean duration of survival of 14 months from a study published before the systematic use of HAART. (87) A case report described an HIV MCD patient who achieved a complete clinical and pathological remission following the use of HAART alone. (88) Another study identified four HIV MCD patients who received HAART alone as treatment with resolution of constitutional symptoms within three months of starting HAART. (89)

\section{Follow-up and Prognosis}

HIV MCD is often a relapsing and remitting disease. Relapse flares may occur at any CD4 count and are not thought to be prevented by HAART and control of the HIV virus. (18, 20, $83,87,90)$ Thus far, there is little data available on second or subsequent line therapy in these patients. HIV MCD also has a high risk of progression to NHL. In a study of $60 \mathrm{HIV}$ infected individuals with MCD, and a median follow-up period of 20 months, 14 patients developed HHV8-associated NHL, which is 15-fold the expected incidence in the general HIV-positive population. (91) Similarly in an Australian study of 11 patients with HIV MCD, with a median follow-up of 48 months, four patients developed lymphoma. (90) A few studies have examined imaging methods for monitoring these patients with HIV MCD and have suggested that PET/CT may be useful for detecting active disease. $(92,93)$ 


\section{Conclusion}

Given the limited amount of data available, it is difficult to make definitive conclusions regarding the optimal treatment for HIV MCD. Currently the most data is available on the use of rituximab, and this is often used alone or in combination with chemotherapy as first line treatment depending on how aggressive the disease appears in a given individual. All patients with HIV MCD should be followed at regular intervals given the relapsing, remitting nature of the disease. A limited number of studies suggest that PET scans may be useful for monitoring disease activity in these patients, but data is not available in regards to how often scans should be done, or whether they should be done only if a patient exhibits symptoms of recurrence. Randomized, clinical trials are needed to determine the optimal treatment and management of these patients.

\section{Acknowledgements}

We would like to acknowledge the Department of Health and Human Services and the National Institute of Health for providing grant support with grant numbers CA121947 and AI28697.

\section{References}

1. Moore DF, Preti A, Tran SM. Prognostic implications following an indeterminate diagnostic workup of lymphoma. Blood. 1996; 88(Suppl. 1) 229a (abstract).

2. Castleman B, Towne V. Case records of the Massachusetts General Hospital: Case No. 40231. N Engl J Med. 1954; 250:1001-1005. [PubMed: 13165944]

3. Castleman B, Inverson L, Menedex V. Localized mediastinal lymph-node hyperplasia resembling thymoma. Cancer. 1956; 9:822-830. [PubMed: 13356266]

4. Festen C, Flendrig JA, Schillings PH. Giant lymphomas. Ned Tijdschr Geneeskd. 1969; 113(43): 1918-1919. [PubMed: 5345776]

5. Menke DM, Tiemann M, Camoriano JK, et al. Diagnosis of Castleman's disease by identification of an immunophenotypically aberrant population of mantle zone B lymphocytes in paraffinembedded lymph node biopsies. Am J Clin Pathol. 1996; 105(3):268-276. [PubMed: 8602606]

6. Dupin N, Diss TL, Kellam P, et al. HHV-8 is associated with a plasmablastic variant of Castleman disease that is linked to HHV-8-positive plasmablastic lymphoma. Blood. 2000; 95(4):1406-1412. [PubMed: 10666218]

7. Powles T, Stebbing J, Bazeos A, et al. The role of immune suppression and HHV-8 in the increasing incidence of HIV-associated multicentric Castleman's disease. Ann Oncol. 2009; 20(4):775-779. [PubMed: 19179554]

8. Lachant NA, Sun NC, Leong LA, Oseas RS, Prince HE. Multicentric angiofollicular lymph node hyperplasia (Castleman's disease) followed by Kaposi's sarcoma in two homosexual males with the acquired immunodeficiency syndrome (AIDS). Am J Clin Pathol. 1985; 83:27-33. [PubMed: 3871303]

9. Rywlin AM, Rosen L, Cabello B. Coexistence of Castleman's disease and Kaposi's sarcoma. Report of a case and a speculation. Am J Dermatopathol. 1983:277-281. [PubMed: 6625119]

10. Chen KT. Multicentric Castleman's disease and Kaposi's sarcoma. Am J Surg Pathol. 1984; 8:287-293. [PubMed: 6711739]

11. Chang Y, Cesarman E, Pessin MS, et al. Identification of herpesvirus-like DNA sequences in AIDS-associated Kaposi's sarcoma [see comments]. Science. 1994; 266:1865-1869. [PubMed: 7997879]

12. Moore PS, Chang Y. Detection of herpesvirus-like DNA sequences in Kaposi's sarcoma lesions from persons with and without HIV infection. New Engl J Med. 1995; 332:1181-1185. [PubMed: 7700310] 
13. Buonaguro FM, Tornesello ML, Beth-Giraldo E, et al. Herpesvirus-like DNA sequences detected in endemic, classic, iatrogenic and epidemic Kaposi's sarcoma (KS) biopsies. Int J Cancer. 1996; 65:25-28. [PubMed: 8543391]

14. Cesarman E, Chang Y, Moore PS, Said JW, Knowles DM. Kaposi's sarcoma-associated herpesvirus-like DNA sequences in AIDS-related body-cavity-based lymphomas. N Engl J Med. 1995; 332:1186-1191. [PubMed: 7700311]

15. Soulier J, Grollet L, Oskenhendler E, et al. Kaposi's sarcomaassociated herpesvirus-like DNA sequences in multicentric Castleman's disease. Blood. 1995; 86:1276-1280. [PubMed: 7632932]

16. Suda T, Katano H, Delsol G, Kakiuchi C, Nakamura T, Shiota M, Sata T, Higashihara M, Mori S. HHV-8 infection status of AIDS-unrelated and AIDS-associated multicentric Castleman's disease. Pathology International. 2001; 51:671-679. [PubMed: 11696169]

17. Izuchukwu IS, Tourbaf K, Mahoney MC. An unusual presentation of Castleman's Disease: a case report. BMC Infect Dis. 2003; 3:20. [PubMed: 12969507]

18. Grandadam M, Dupin N, Calvez V, Gorin I, Blum L, Kernbaum S, Sicard D, Buisson Y, Agut H, Escande JP, Huraux JM. Exacerbations of clinical symptoms in human immunodeficiency virus type 1-infected patients with multicentric Castleman's disease are associated with a high increase in Kaposi's sarcoma herpesvirus DNA load in peripheral blood mononuclear cells. Journal of Infectious Diseases. 1997; 175:1198-1201. [PubMed: 9129085]

19. Bottieau E, Colebunders R, Schroyens W, Van Droogenbroeck J, De Droogh E, Depraetere K, De Raeve H, Van Marck E. Multicentric Castleman's disease in 2 patients with HIV infection, unresponsive to antiviral therapy. Acta Clinica Belgica. 2000; 55:97-101. [PubMed: 10881375]

20. Oksenhendler E, Carcelain G, Aoki Y, Boulanger E, Maillard A, Clauvel JP, Agbalika F. High levels of human herpesvirus 8 viral load, human interleukin-6, interleukin-10, and $\mathrm{C}$ reactive protein correlate with exacerbation of multicentric castleman disease in HIV-infected patients. Blood. 2000; 96:2069-2073. [PubMed: 10979949]

21. Corbellino M, Bestetti G, Scalamogna C, Calattini S, Galazzi M, Meroni L, Manganaro D, Fasan M, Moroni M, Galli M, Parravicini C. Long-term remission of Kaposi sarcoma- associated herpesvirus-related multicentric Castleman disease with anti-CD20 monoclonal antibody therapy. Blood. 2001; 98:3473-3475. [PubMed: 11719390]

22. Boivin G, Cote S, Cloutier N, Abed Y, Maguigad M, Routy JP. Quantification of human herpesvirus 8 by real-time PCR in blood fractions of AIDS patients with Kaposi's sarcoma and multicentric Castleman's disease. Journal of Medical Virology. 2002; 68:399-403. [PubMed: 12226828]

23. Berezne A, Agbalika F, Oksenhendler E. Failure of cidofovir in HIV-associated multicentric Castleman disease. Blood. 2004; 103:4368-4369. [PubMed: 15155471]

24. Casper C, Nichols WG, Huang ML, Corey L, Wald A. Remission of HHV-8 and HIV-associated multicentric Castleman disease with ganciclovir treatment. Blood. 2004; 103:1632-1634. [PubMed: 14615380]

25. Katano H, Sato Y, Kurata T, Mori S, Sata T. Expression and localization of human herpesvirus 8encoded proteins in primary effusion lymphoma, Kaposi's sarcoma, and multicentric Castleman's disease. Virology. 2000; 269:335-344. [PubMed: 10753712]

26. Katano H, Sato Y, Itoh H, Sata T. Expression of human herpesvirus 8 (HHV-8)-encoded immediate early protein, open reading frame 50, in HHV-8-associated diseases. Journal of Human Virology. 2001; 4:96-102. [PubMed: 11437319]

27. Foss HD, Araujo I, Demel G, Klotzbach H, Hummel M, Stein H. Expression of vascular endothelial growth factor in lymphomas and Castleman's disease. Journal of Pathology. 1997; 183:44-50. [PubMed: 9370946]

28. Nishi J, Arimura K, Utsunomiya A, Yonezawa S, Kawakami K, Maeno N, Ijichi O, Ikarimoto N, Nakata M, Kitajima I, Fukushige T, Takamatsu H, Miyata K, Maruyama I. Expression of vascular endothelial growth factor in sera and lymph nodes of the plasma cell type of Castleman's disease. British Journal of Haematology. 1999; 104:482-485. [PubMed: 10086783]

29. Van Kooten C, Rensink I, Aarden L, van Oers R. Effect of IL-4 and IL-6 on the proliferation and differentiation of B-chronic lymphocytic leukemia cells. Leukemia. 1993; 7:618-624. [PubMed: 8464239] 
30. Yoshizaki K, Matsuda T, Nishimoto N, Kuritani T, Taeho L, Aozasa K, Nakahata T, Kawai H, Tagoh H, Komori T. Pathogenic significance of interleukin-6 (IL-6/BSF-2) in Castleman's disease. Blood. 1989; 74:1360-1367. [PubMed: 2788466]

31. Brandt SJ, Bodine DM, Dunbar CE, Nienhuis AW. Dysregulated interleukin 6 expression produces a syndrome resembling Castleman's disease in mice. Journal of Clinical Investigation. 1990; 86:592-599. [PubMed: 2384605]

32. Beck JT, Hsu SM, Wijdenes J, Bataille R, Klein B, Vesole D, Hayden K, Jagannath S, Barlogie B. Brief report: alleviation of systemic manifestations of Castleman's disease by monoclonal antiinterleukin-6 antibody. The New England Journal of Medicine. 1994; 330:602-605. [PubMed: 8302342]

33. Nishimoto N, Sasai M, Shima Y, Nakagawa M, Matsumoto T, Shirai T, Kishimoto T, Yoshizaki K. Improvement in Castleman's disease by humanized anti-interleukin-6 receptor antibody therapy. Blood. 2000; 95:56-61. [PubMed: 10607684]

34. Molden J, Chang Y, You Y, Moore PS, Goldsmith MA. A Kaposi's sarcoma-associated herpesvirus-encoded cytokine homolog (vIL-6) activates signaling through the shared gp130 receptor subunit. J Biol Chem. 1997; 272:19625-19631. [PubMed: 9235971]

35. Osborne J, Moore PS, Chang Y. KSHV-encoded viral IL-6 activates multiple human IL-6 signaling pathways. Hum Immunol. 1999; 60:921-927. [PubMed: 10566591]

36. Mullberg J, Geib T, Jostock T, et al. IL-6 receptor independent stimulation of human gp130 by viral IL-6. J Immunol. 2000; 164:4672-4677. [PubMed: 10779772]

37. Li H, Wang H, Nicholas J. Detection of direct binding of human herpesvirus 8-encoded interleukin-6 (vIL-6) to both gp130 and IL-6 receptor (IL-6R) and identification of amino acid residues of vIL-6 important for IL-6R-dependent and -independent signaling. J Virol. 2001; 75:3325-3334. [PubMed: 11238858]

38. Boulanger MJ, Chow DC, Brevnova E, et al. Molecular mechanisms for viral mimicry of a human cytokine: activation of gp130 by HHV-8 interleukin-6. J Mol Biol. 2004; 335:641-654. [PubMed: 14672670]

39. Aoki Y, Jaffe ES, Chang Y, et al. Angiogenesis and hematopoiesis induced by Kaposi's sarcomaassociated herpesvirus-encoded interleukin-6. Blood. 1999; 93:4034-4043. [PubMed: 10361100]

40. Parravinci C, Corbellino M, Paulli M, Magrini U, Lazzarino M, Moore PS, Chang Y. Expression of a virus-derived cytokine, KSHV vIL-6, in HIV-seronegative Castleman's disease. American Journal of Pathology. 1997; 151:1517-1522. [PubMed: 9403701]

41. Menke DM, Chadbum A, Cesarman E, Green E, Berenson J, Said J, Tiemann M, Parwaresch R, Thome SD. Analysis of the human herpesvirus 8 (HHV-8) genome and HHV-8 vIL-6 expression in archival cases of castleman disease at low risk for HIV infection. American Journal of Clinical Pathology. 2002; 117:268-275. [PubMed: 11863223]

42. Cannon JS, Nicholas J, Orenstein JM, Mann RB, Murray PG, Browning PJ, DiGiuseppe JA, Cesarman E, Hayward GS, Ambinder RF. Heterogeneity of viral IL-6 expression in HHV-8associated diseases. Journal of Infectious Diseases. 1999; 180:824-828. [PubMed: 10438372]

43. Aoki Y, Tosato G, Fonville TW, Pittaluga S. Serum viral interleukin-6 in AIDS-related multicentric Castleman disease. Blood. 2001; 97:2526-2527. [PubMed: 11307774]

44. Casper C. The aetiology and management of Castleman disease at 50 years: translating pathophysiology to patient care. British Journal of Haematology. 2005; 129:3-17. [PubMed: 15801951]

45. Herrada J, Cabanillas F, Rice L, Manning J, Pugh W. The clinical behavior of localized and multicentric Castleman disease. Annals of Internal Medicine. 1998; 128:657-662. [PubMed: 9537940]

46. Bowne WB, Lewis JJ, Filippa DA, Niesvizky R, Brooks AD, Burt ME, Brennan MF. The management of unicentric and multicentric Castleman's disease: a report of 16 cases and a review of the literature. Cancer. 1999; 85:706-717. [PubMed: 10091744]

47. Chronowski GM, Ha CS, Wilder RB, Cabanillas F, Manning J, Cox JD. Treatment of unicentric and multicentric Castleman disease and the role of radiotherapy. Cancer. 2001; 92:670-676. [PubMed: 11505414] 
48. Oksenhendler E, Duarte M, Soulier J, et al. Multicentric Castleman's disease in HIV infection: A clinical and pathological study of 20 patients. AIDS. 1996; 10:61-67. [PubMed: 8924253]

49. Van Rhee F, Stone K, Szmania S, Barlogie B, Singh Z. Castleman Disease in the 21st Century: An Update on Diagnosis, Assessment, and Therapy. Clinical Advances in Hematology \& Oncology. 2010; 8(7):486-498. [PubMed: 20864917]

50. Dham A, Peterson BA. Castleman disease. Curr Opin Hematol. 2007; 14:354-359. [PubMed: 17534161]

51. Frizzera G, Peterson B, Bayrd E, et al. A systemic lymphoproliferative disorder with morphologic features of Castleman's disease: clinical findings and clinicopathologic correlations in 15 patients. J Clin Oncol. 1985; 3:1202-1216. [PubMed: 4031967]

52. Peterson BA, Frizzera G. Multicentric Castleman's disease. Seminars in Oncology. 1993; 20:636647. [PubMed: 8296200]

53. Schmidt SM, Raible A, Kortum F, et al. Successful treatment of multicentric Castleman's disease with combined immunochemotherapy in an AIDS patient with multiorgan failure. Leukemia. 2008; 22(9):1782-1785. [PubMed: 18449205]

54. Hall PA, Donaghy M, Cotter FE, Stansfeld AG, Levison DA. An immunohistological and genotypic study of the plasma cell form of Castleman's disease. Histopathology. 1989; 14:333346. discussion 429-332. [PubMed: 2737612]

55. Dupin N, Diss TL, Kellam P, et al. HHV-8 is asso- ciated with a plasmablastic variant of Castleman disease that is linked to HHV-8-positive plasmablastic lymphoma. Blood. 2000; 95(4): 1406-1412. [PubMed: 10666218]

56. Dupin N, Fisher C, Kellam P, et al. Distribution of human herpesvirus-8 latently infected cells in Kaposi's sarcoma, multicentric Castleman's disease, and primary effusion lymphoma. Proc Natl Acad Sci USA. 1999; 96(8):4546-4551. [PubMed: 10200299]

57. Du MQ, Liu H, Diss TC, et al. Kaposi sarcoma-associated herpesvirus infects monotypic (IgM lambda) but polyclonal naive B cells in Castleman disease and associated lymphoproliferative disorders. Blood. 2001; 97(7):2130-2136. [PubMed: 11264181]

58. Judde JG, Lacoste V, Briere J, et al. Monoclonality or oligoclonality of human herpesvirus 8 terminal repeat sequences in Kaposi's sarcoma and other diseases. J Natl Cancer Inst. 2000; 92(9): 729-736. [PubMed: 10793109]

59. Gerard L, Berezne A, Galicier L, et al. Prospective study of rituximab in chemotherapy-dependent human immunodeficiency virus associated multicentric Castleman's disease: ANRS 117 CastlemaB Trial. J Clin Oncol. 2007; 25(22):3350-3356. [PubMed: 17664482]

60. Scott D, Cabral L, Harrington W Jr. Treatment of HIV-associated multicentric Castleman's disease with oral etoposide. Am J Hematol. 2001; 66:148-150. [PubMed: 11421297]

61. Weisenburger DD, Nathwani BN, Winberg CD, Rappaport H. Multicentric angiofollicular lymph node hyperplasia: a clinicopathologic study of 16 cases. Hum Pathol. 1985; 16(2):162-172. [PubMed: 2579015]

62. Bestawros A, Michel R, Seguin C, Routy JP. Multicentric Castleman's disease treated with combination chemotherapy and rituximab in four HIV positive men: a case series. Am J Hematol. 2008; 83(6):508-511. [PubMed: 18027834]

63. Oksenhendler E. HIV-associated multicentric Castleman disease. Curr Opin HIV AIDS. 2009; 4(1):16-21. [PubMed: 19343828]

64. Bower M. How I treat HIV-associated multicentric Castleman Disease. Blood. 2010; 116:44154421. [PubMed: 20688959] This article provides as review of clinical management options for HIV MCD based on published literature and the author's personal experience.

65. Nishimoto N, Kanakura Y, Aozasa K, et al. Humanized anti-interleukin-6 receptor antibody treatment of multicentric Castleman disease. Blood. 2005; 106(8):2627-2632. [PubMed: 15998837]

66. Van Rhee F, Fayad L, Voorhees P, Furman R, Lonial S, Borghaei H, Sokol L, Crawford J, Cornfield M, Qi M, Qin X, Herring J, Casper C, Kurzrock R. Siltuximab, a Novel AntiInterleukin-6 Monoclonal Antibody, for Castleman's Disease. Journal of Clinical Oncology. 2010 Published ahead of print. This article reports the interim results of a phase I study evaluating the use of Siltuximab in patients with CD. 
67. Marcelin A, Aaron L, Mateus C, Gyan E, Gorin I, Viard J, Calvez V, Dupin N. Rituximab therapy for HIV-associated Castleman disease. Blood. 2003; 102(8):2786-2788. [PubMed: 12842986]

68. Bower M, Powles T, Williams S, et al. Brief communication: rituximab in HIV-associated multicentric Castleman disease. Ann Intern Med. 2007; 147(12):836-839. [PubMed: 18087054]

69. Neuville S, Agbalika F, Rabian C, Briere J, Molina JM. Failure of rituximab in human immunodeficiency virus-associated multicentric Castleman disease. Am J Hematol. 2005; 79(4): 337-339. [PubMed: 16044438]

70. Buchler T, Dubash S, Lee V, et al. Rituximab failure in fulminant multicentric HIV/human herpesvirus 8-associated Castleman's disease with multiorgan failure: report of two cases. AIDS. 2008; 22(13):1685-1687. [PubMed: 18670234]

71. Powles T, Stebbing J, Montoto S, Nelson M, Gazzard B, Orkin C, Webb A, Bower M. Rituximab as retreatment for rituximab pretreated HIV-associated multicentric Castleman disease. Blood. 2007; 110(12):4132-4133. [PubMed: 18024800]

72. Michot JM, Gerard L, Burcheri S, Fieschi S, Oksenhendler E, Galicier L. Impact of Rituximab on Incidence of NHL in Patients with HIV-associated MCD. CROI. 2011 Abstract 83. This was a retrospective study suggesting that usage of rituximab for treatment of HIV MCD decreased risk of progression to NHL and increased overall survival.

73. Hoffmann C, Muller M, Schmid H, Teutsch C, Van Lunzen J, Wolf T, Esser S, Wyen C, Bogner J, Arasteh K. Improved outcome in Patients with HIV-associated Multicentric Castleman's Disease during recent years: An effect of Rituximab? CROI. 2011 Abstract 861. This was a retrospective study which found that clinical outcome for patients with HIV MCD were improved during recent years suggesting improved efficacy of rituximab-based treatment strategies.

74. Weisenburger DD, Nathwani BN, Winberg CD, Rappaport H. Multicentric angiofollicular lymph node hyperplasia: a clinicopathologic study of 16 cases. Human Pathology. 1985; 16:162-172. [PubMed: 2579015]

75. Kumari P, Schechter GP, Saini N, Benator DA. Successful treatment of human immunodeficiency virus-related Castleman's disease with interferon-alpha. Clinical Infectious Diseases. 2000; 31:602-604. [PubMed: 10987728]

76. Nord JA, Karter D. Low dose interferon-alpha therapy for HIV-associated multicentric Castleman's disease. International Journal of STD and AIDS. 2003; 14:61-62. [PubMed: 12590797]

77. Jung CP, Emmerich B, Goebel FD, Bogner JR. Successful treatment of a patient with HIVassociated multicentric Castleman disease (MCD) with thalidomide. American Journal of Hematology. 2004; 75:176-177. [PubMed: 14978701]

78. Lee FC, Merchant SH. Alleviation of systemic manifestations of multicentric Castleman's disease by thalidomide. American Journal of Hematology. 2003; 73:48-53. [PubMed: 12701121]

79. Klass CM, Offermann MK. Targeting human herpesvirus- 8 for treatment of Kaposi's sarcoma and primary effusion lymphoma. Curr Opin Oncol. 2005; 17(5):447-455. [PubMed: 16093794]

80. Corbellino M, Bestetti G, Scalamogna C, et al. Long-term remission of Kaposi sarcoma-associated herpesvirus-related multicentric Castleman disease with anti-CD20 monoclonal antibody therapy. Blood. 2001; 98(12):3473-3475. [PubMed: 11719390]

81. Senanayake S, Kelly J, Lloyd A, Waliuzzaman Z, Goldstein D, Rawlinson W. Multicentric Castleman's disease treated with antivirals and immunosuppressants. J Med Virol. 2003; 71(3): 399-403. [PubMed: 12966545]

82. Revuelta MP, Nord JA. Successful treatment of multicentric Castleman's disease in a patient with human immunodeficiency virus infection. Clin Infect Dis. 1998; 26(2):527. [PubMed: 9502499]

83. Casper C, Nichols WG, Huang ML, Corey L, Wald A. Remission of HHV-8 and HIV-associated multicentric Castleman disease with ganciclovir treatment. Blood. 2004; 103(5):1632-1634. [PubMed: 14615380]

84. Mylona EE, Baraboutis IG, Lekakis LJ, Georgiou O, Papastamopoulos V, Skoutelis A. Multicentric Castleman's disease in HIV infection: a systematic review of the literature. AIDS Rev. 2008; 10(1):25-35. [PubMed: 18385778] 
85. Dupin N, Krivine A, Calvez V, Gorin I, Franck N, Escande JP. No effect of protease inhibitor on clinical and virological evolution of Castleman's disease in an HIV-1-infected patient. AIDS. 1997; 11(11):1400-1401. [PubMed: 9302455]

86. Zietz C, Bogner JR, Goebel FD, Lohrs U. An unusual cluster of cases of Castleman's disease during highly active antiretroviral therapy for AIDS. N Engl J Med. 1999; 340(24):1923-1924. [PubMed: 10375310]

87. Aaron L, Lidove O, Yousry C, Roudiere L, Dupont B, Viard J. Human Herpesvirus 8-Positive Castleman Disease in Human Immunodeficiency Virus-Infected Patients: The Impact of Highly Active Antiretroviral Therapy. Clin Infect Dis. 35:880-882. [PubMed: 12228826]

88. Sprinz E, Jeffman M, Liedke P, Putten A, Schwartsmann G. Successful treatment of AIDS-related Castleman's disease following the administration of highly active antiretroviral therapy (HAART). Ann Oncol. 2004; 15(2):356-358. [PubMed: 14760135]

89. Lee SM, Edwards SG, Chilton DN, Ramsay A, Miller RF. Highly active antiretroviral therapy alone may be an effective treatment for HIV-associated multicentric Castleman's disease. Haematologica. 2010; 95(11):1979-1981. [PubMed: 20801900]

90. Loi S, Goldstein D, Clezy K, Milliken ST, Hoy J, Chipman M. Castleman's disease and HIV infection in Australia. HIV Med. 2004; 5(3):157-162. [PubMed: 15139981]

91. Oksenhendler E, Boulanger E, Galicier L, Du M, Dupin N, Diss TC, Hamoudi R, Daniel M, Agbalika F, Boshoff C, Clauvel J, Isaacson PG, Meignin V. High incidence of Kaposi sarcomaassociated herpesvirus-related non-Hodgkin lymphoma in patients with HIV infection and multicentric Castleman disease. Blood. 2002; 99:2331-2336. [PubMed: 11895764]

92. Barker R, Kazmi F, Stebbing J, Ngan S, Chinn R, Nelson M, O’Doherty M, Bower M. FDG$\mathrm{PET} / \mathrm{CT}$ imaging in the management of HIV-associated multicentric Castleman's disease. Eur J Nucl Med Mol Imaging. 2009; 36:648-652. [PubMed: 19050873]

93. Polizzotto M, Millo C, Uldrick T, Aleman K, Whatley M, Marshall V, Whitby D, Steinberg S, Little R, Yarchoan R. 18-Flouro-D-deoxyglucose PET in the Diagnosis and Monitoring of KSHVMCD: Correlation with Clinical, Inflammatory and Virologic Parameters. CROI. 2011 Abstract 862. 


\section{Key Points}

- $\quad$ HHV-8, VEGF, and IL-6 are thought to play a role in the pathogenesis of HIV MCD

- $\quad$ Common presenting symptoms of HIV MCD include fever, night sweats, fatigue, weight loss, lymphadenopathy, hepatosplenomegaly, respiratory symptoms, and edema.

- $\quad$ Pathologic examination of an excised lymph node is necessary to establish the diagnosis of HIV MCD.

- Currently, rituximab alone or in combination with chemotherapy is most commonly used for management of MCD.

- $\quad$ HIV MCD is a relapsing remitting disease. 


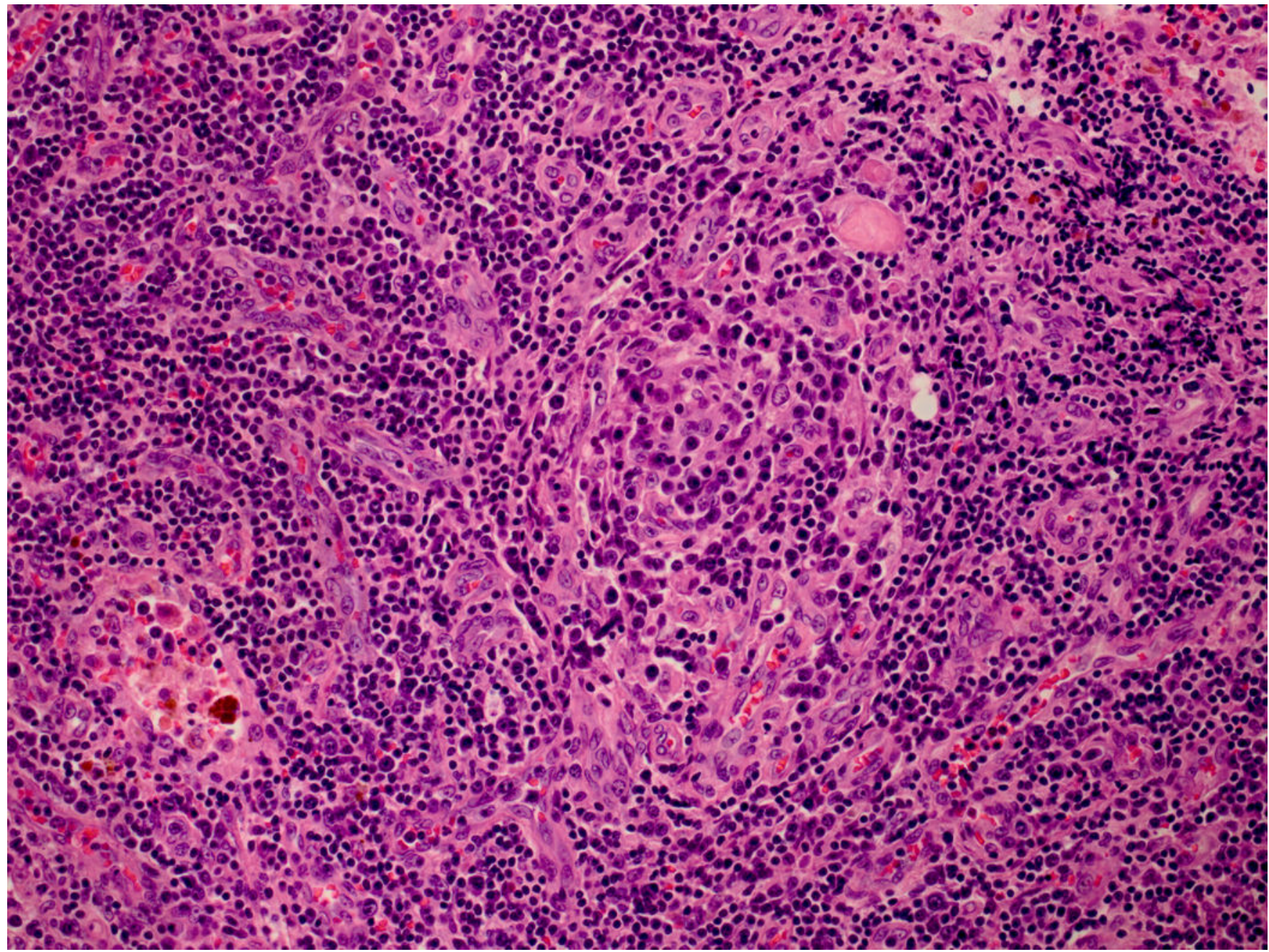

Figure 1.

High-power field of a hyperplastic germinal center with vascular proliferation from a patient with HIV MCD. Image courtesy of Dr. Jonathan Said, UCLA Department of Pathology and Laboratory Medicine. 

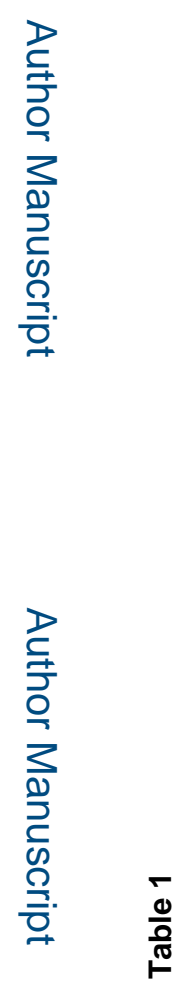

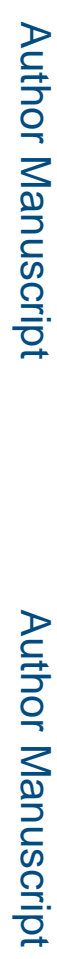

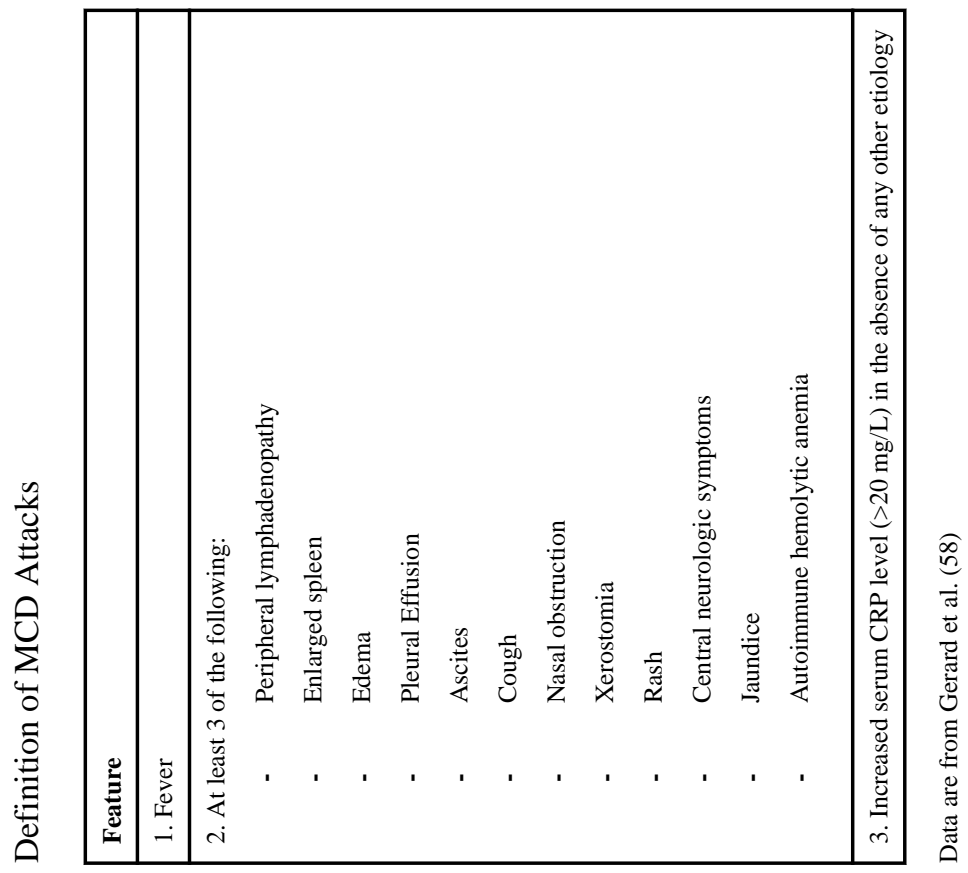

Curr Opin Oncol. Author manuscript; available in PMC 2015 March 29. 